\title{
機能印象材の粘弾性に関する基礎的研究
}

\author{
九州歯科大学理工学教室 (指導：林 一郎教授)
}

大学院生 佐 藤 鎮 城

（昭和46年12月17日受理）

（本論文の要旨は昭和46年12月16日九州歯科学会12月例会において発表した）

\section{FUNDAMENTAL STUDIES ON THE VISCOELASTICITY OF THE DYNAMIC IMPRESSION MATERIAL}

\author{
By \\ Shigeki SATO \\ Department of Dental Physicotechnology (Director: Prof. Ichiro HAYASHI) \\ Kyushu Dental College, Kitakyushu Japan
}

The dynamic impression material changes in its physical properties with the lapse of time after mixing. To make clear such changes, the author measured relaxation of the trially made dynamic impression materials with a relaxometer and examined their viscoelastic behaviors. The results will be given in the following:

1. There are two types of commercial dynamic impression material. In one of them, relaxation time is extented, while in the other, reduced with a rise in modulus of elasticity.

2. The effect of ethanol in the mixing liquid on the mixture of the trially made dynamic impression material is that it acts as an accelerator at the initial period of hardening and as a plasticizer at the subsequent period.

\section{I ま え がき}

機能印象を採るに当っては，機能印象材の物性1 13)を 十分認識しておくととが不可欠の重要事である。一定の 咬合圧がロ腔粘膜とトレー（義蒾）との間の機能印象材 に加った場合，印象材がいかなる流動変形をするかを知 り，その性質を利用して機能印象をとるのであるが，て れを完全にまっとうするには，被印象体である患者の口 腔粘膜の状態をも十分に調へ，乙れから材料がいかなる 力を受けて流動変形をきたすかを知っておかなければな らない14,15). しかし現在のところ印象体側も被印象体側 も16,17)その物性について，あまり具体的には研究されて いない。 そこで著者は西科理工学の立場から印象体側で ある機能印象材について市販の印象材之類似の粘弾性挙 動を示す印象材を試作し18,19)，それを中心にずり応力紱
和測定ならびに引張り応力緩和测定をおてなって，その 応力緩和機構を明らかにした，被印象体側である口腔粘 膜の粘弾性挙動に関しては, 解剖・生理学的研究に俟つ ことにする.

\section{1 試料の種類}

\section{II 実 験 試 料}

本実験に使用した試料は，当教室で試作した機能印象 材 HSFE と, 現在市販されている機能印象材である八 イソフト,ダイナミックス, ハイドロキャスト（以下 HS，DM，HC と略記する)の 4 種類である. 試作した 印象材は，(HS の粉末）に液として（フタル酸ブチル ベンジルトエタノール）を加えて反応させたものであ る. 液の組成については表】に示す。測定に供した試 
表 I 試作印象材 HSFE の液の組成之粉液比

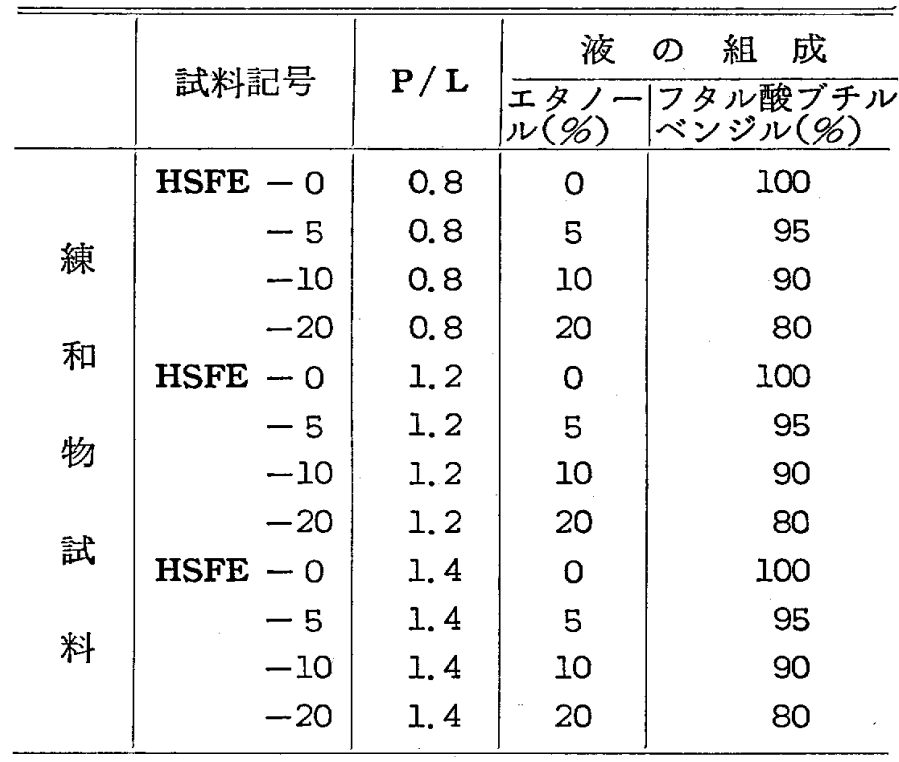

表 2 市販印象材の粉液比

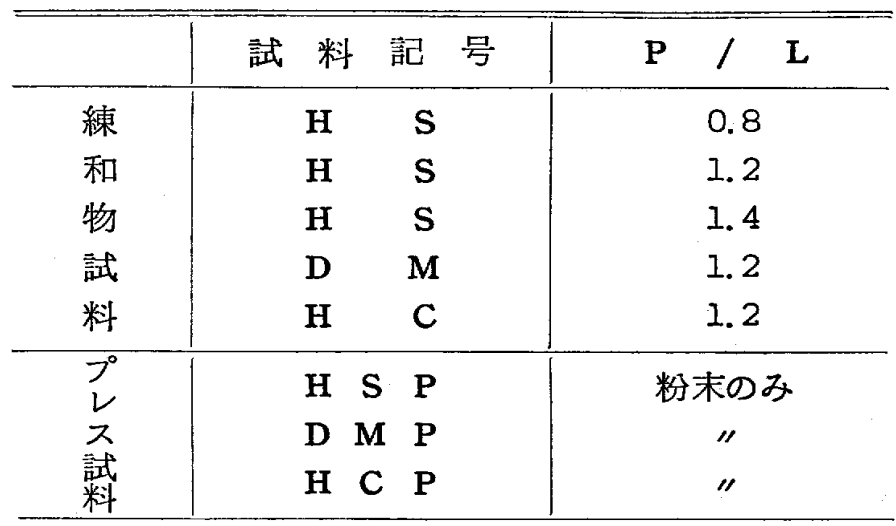

料の粉液比 $(\mathrm{P} / \mathrm{L}$ 比) は, HSFE 之 HS では, 0.8 , 1.2，1.4の3 種類，DM と HCでは1.2とした。な打粉 末のみをプレスして作製した試料についても測定を行な った（表 I，2）. 表中，HS，DM，HC，の後につく P は，P を付記した試料がそれぞれの機能印象材の粉末の みをプレスして製作した試料であるてとを意味してい る．また HSFE の後に付記した0，5，10，20の数字 は液中のエタノールの重量百分率を示す。

\section{2 練和物試料の作製法}

練和方法は, 室温 $\left.26^{\circ} \mathrm{C} 20\right)$ のもでビーカーに一定量 の粉末をとり，規定の粉液比になるように液を加え，直 ちに練和を開始する．練和には歯科用セメントスパチュ ラを用い，15秒間できるだけ速く擋拌する．練和開始か ら60秒以内に，すでにプレートのセットされているセル の中に流してむ.

\section{3 プレス試料の作製法}

アルミ箔を張った $16 \times 16 \times C .3 \mathrm{~cm}^{3}$ の大きさの 2 枚の
しんちゆう板の間に,HS，DM，HC の粉末約 $3 \mathrm{~g}$ を直径 約 $10 \mathrm{~cm}$, 厚さ約 $0.3 \mathrm{~mm}$ の円板状にしてはさみ, $180^{\circ} \mathrm{C}$ に加熱されたプレスで $300 \mathrm{~kg} / \mathrm{cm}^{2}$ の圧を 5 分間かける. 加王終了後直ちにプレスに流水（水道水を直接用いる） を各回同一の条件で灌流せしぬて冷却し，厚さ0.032 cm のフイルム板を得た。

てれを鋭利なカミソリで短冊形（幅0.127〜0.145 cm 長さ4.70〜 $5.25 \mathrm{~cm}$ ) に切り試料片とした21).

4 試料の検定

a）比重ならびに平均粒度；测定にはベックマン空気 比較式比重計，島津直示平均粒度計を使用した。測定結 果は表 3 に示す.

表 3 市販印象材の比重之粉末の平均粒度

\begin{tabular}{|c|c|c|c|c|}
\hline & 試 料 & $\mathrm{H} \quad \mathrm{S}$ & D $\quad M$ & H C \\
\hline 比 重 & 粉 末 & 1.29 & 1.26 & 1. 14 \\
\hline $\mathrm{g} / \mathrm{cm}^{\mathrm{s}}$ & 液 & 1.03 & 1.03 & 1.04 \\
\hline \multicolumn{2}{|c|}{ 平均粒度 $(\mu)$} & 95 & 48 & 90 \\
\hline
\end{tabular}

b) 顕微鏡写真 ; 市 販機能印 象材の 粉末粒子の形態 亡, これらに液を加えた時の形状変化を偏光顕微鏡 $(X$ 200)で観察した.

HS，HC の粉末は, 大小種々の球状粒子からなり, DM は少数の不整球状の大粒子と，大部分をしめる不整 形の微粒子からなっている，観察は，それぞれの試料の 比較的大きい粒子について行なった（図1〜3）. また それらの粒子のそれぞれに液を滴下した後，5，10， 150分の 3 時点における顕微鏡像を観察した（図 4〜 12).

HS の粒子は，液に接触した表 層部から膨潤が起こ り，乙の膨潤したものは, 徐々に液中に溶解していく. 液に接触してから60分でその直径は最初の約 $2 / 3$ となり。 150分で粒子は完全に液中に溶解し均一な溶液となる. てれに対して，DM，HC の粒子は液を滴下しても何ら の形状変化を示さず粒子の大きさは 1 日後でも変らな い.

\section{III 緩和測定の装置と方法}

練和物試料にはずり応力緩和測定装置, プレス試料に は引張り応力緩和測定装置をそれぞれ使用した。 なおゴ

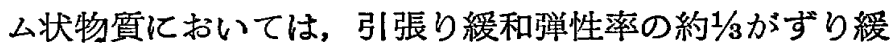
和弾性率に相当する22)ので，前者のデーターの1/3をとる ことにより両者を比較することは可能である. 


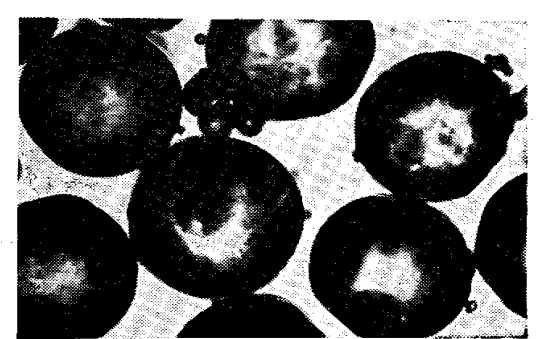

図 1 H S 粒子

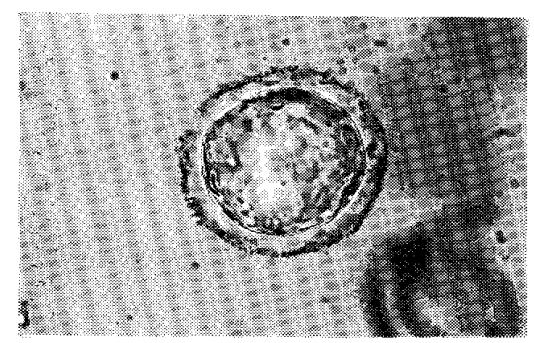

図 4 H S 湤の滴下 後 5 分

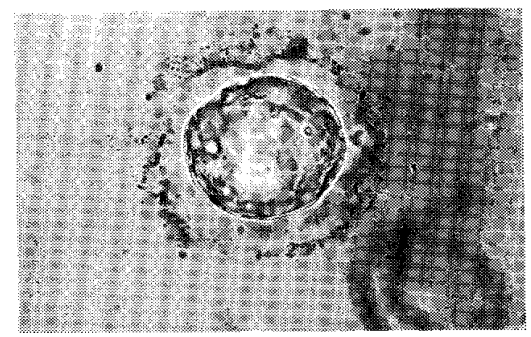

図 7 H S 液の滴下 後10分

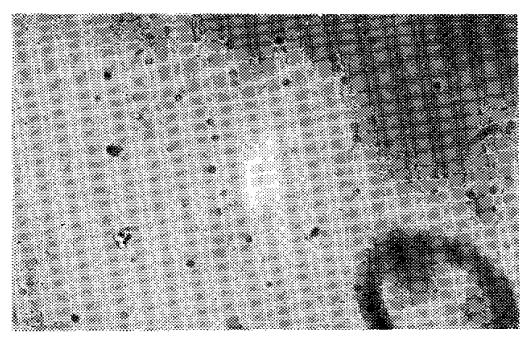

図10 H S液の滴下 後150分

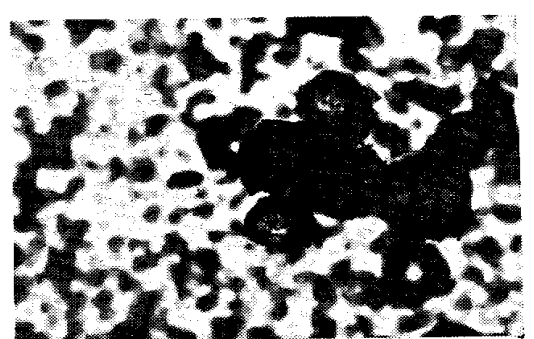

図 2 DM 粒子

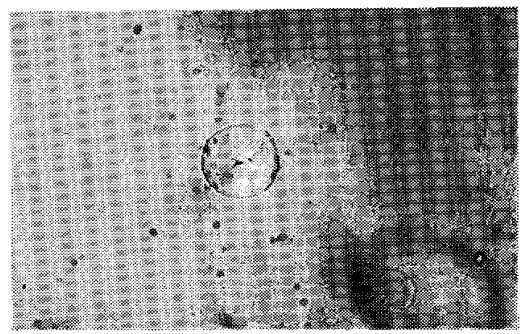

図 5 D M液の滴下 後 5 分

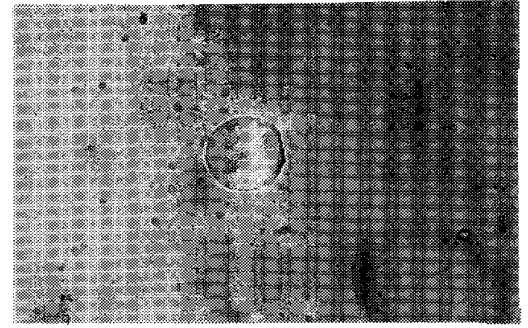

図8 D M液の滴下 後10分

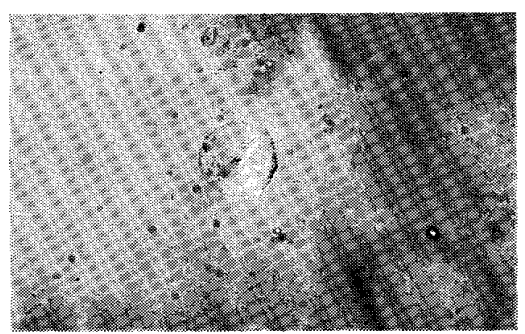

図11 D M液の滴下 後150分

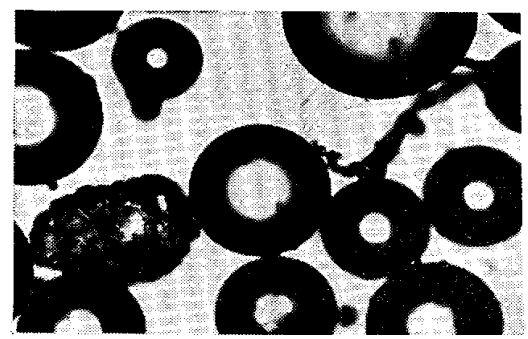

図 $3 \mathrm{H} \mathrm{C}$ 粒子

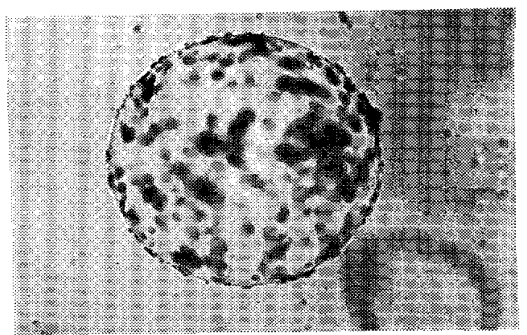

図6 H C液の滴下 後 5 分

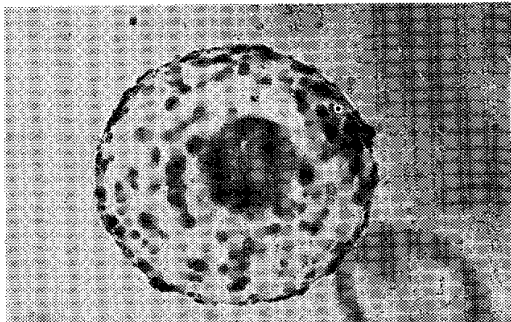

図 9，H C液の滴下 後10分

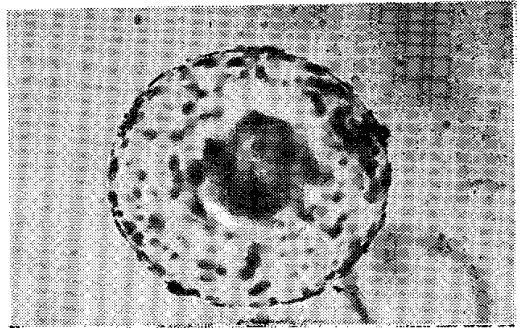

図12 H C液の滴下 後150分

\section{1 ずり応力緩和}

a) 測定装置

練和物試料の測定には九大工学部高柳研で試作された 高分子溶融物用平板式応力緩和計を使用した 23 25)。装 置の全景は図13，その構成模型図は図14に示す。

b) 測定方法

箱型のセルの中央にプレートをセットし，練和物をセ ル中に注入する．注入量はプレートの下端から $85 \mathrm{~mm} の$ 水準までとする，測定は直接セルに連結させた微動ネジ
で瞬間的にセルに一定の変位を与え，ての時のプレート に発生する力を，てれに值結されている非接着型ワイヤ ストレィングージ〔東洋測器K. K. 製, TI-500-120型, 最大荷重500g】を通してレコーダー〔松下電器K. K. 製】に記録しプレートに発生した剪断力の時間的変化 を測定した。セルの変位量はダイアルゲージ〔精度0.01 $\mathrm{mm}$ 】で読みとった，七ルならびにプレートの形状は図 14に示す. 各部位の寸法はそれぞれ $\mathrm{A}=90 \mathrm{~mm}, \mathrm{~B}=70$ $\mathrm{mm}, \mathrm{D}=10 \mathrm{~mm}, L=85 \mathrm{~mm}, \quad b=20 \mathrm{~mm}, \quad d=0.3 \mathrm{~mm}$ 


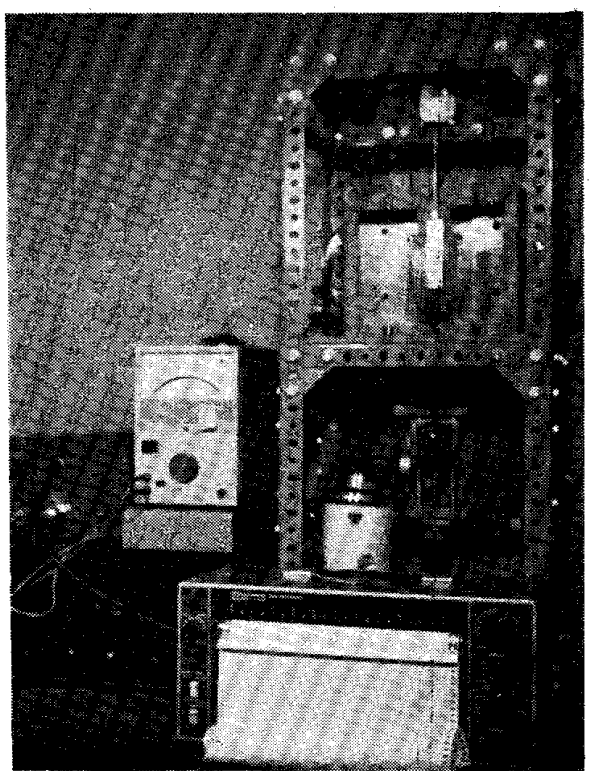

図13 平板式ずり応力緩和測定機の全景

\section{である.}

c) ずり緩和弾性率 $\mathrm{Gr}(\mathrm{t})$ の求め方

ずり緩和弾性率 $\operatorname{Gr}(\mathrm{t})$ は，Hookeの法則より

$$
\mathrm{Gr}(\mathrm{t})=\frac{\mathrm{s}(\mathrm{t})}{\gamma}=\frac{490}{\mathrm{Ss} \cdot \boldsymbol{\gamma}} \mathrm{S}(\mathrm{t})
$$

で与えられる26).

ただし， $\mathrm{S}(\mathrm{t})$ は剪断力 $(\mathrm{g}$ 重)，Ss は $(\mathrm{b} \times \mathrm{L})$ で練和 物之接触しているプレートの片側の面積 $\left(\mathrm{cm}^{2}\right), \gamma$ は ひずみである。ずり応力減衰状態の比較には，1.2 秒後 の応力 $(\mathrm{s}(1.2)$ ) を基準にとり，各時間での応力の值（ $s(t))$ との比く相対ずり応力>を用いた。

\section{2 引張り応力緩和}

a) 測定装置

当教室で作製した応力緩和測定装置を使用した27)．装 置全景は図15，その構成模型図は図16に示す。

b) 測定方法

短冊形のプレス試料の両端をチャックではさみそこの 一方の端を上部に固定されたストレィンゲージ〔東洋測 器K. K. 製，TI-200-120型，最大荷重200g】につなぎ, 下端に瞬間的に一定の変位を与えて，ストレィンゲージ に発生する応力の時間的変化を電子管式自動平衡記録装 置〔東洋測器K. K. 製〕在用いて1, 500 秒間测定し，そ の值より引張り応力を算出した，測定温度は $26^{\circ} \mathrm{C}$ であ

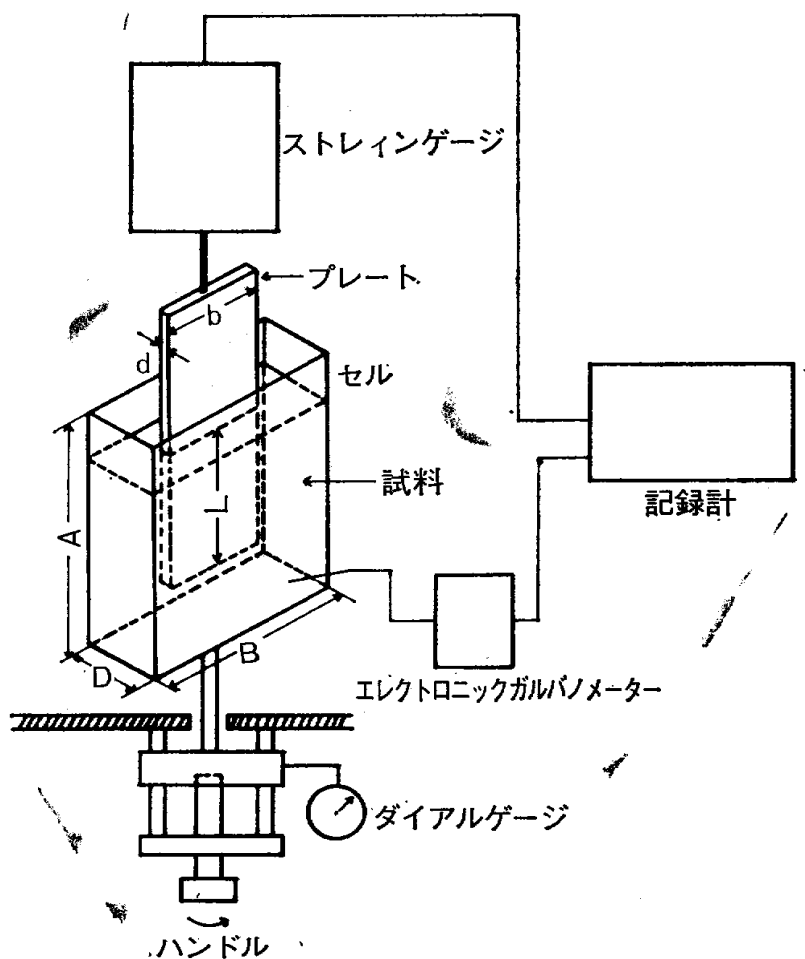

図14 平板式ずり応力緩和測定譏の構成模型図 $ろ^{20)}$.

b) 引張り緩和弾性率 $\operatorname{Er}(t)$ の求ぬ方

引張り緩和弾性率 $\operatorname{Er}(\mathrm{t})$ は, Hooke の法則より

$$
\operatorname{Er}(t)=\frac{f(t)}{\varepsilon}=\frac{9801}{S e \cdot \Delta l} F(t)
$$

で与えられる。

ただし， $f(t)$ は試料に発生する引張り応力 (dyne/c $\mathrm{m}^{2}$ ), $\mathrm{F}(\mathrm{t})$ は引引張り荷重 ( $\mathrm{g}$ 重), Seは試料の断面積 (c $\mathrm{m}^{2}$ ), عは引張りひずみ, 1 は試料のチャック間距離（c $\mathrm{m}), \Delta 1$ は引張り変位量 $(\mathrm{cm})$ である.

引張り応力減衰状態の比較には，1.2秒後の応力（f (1.2)）を基準にとり，各時間での応力の值 $(\mathbf{f}(\mathbf{t}))$ 之 の比<相対引張り応力>在用いた。

\section{IV 実 験 結 果}

すべての HSFE について, 練和開始後試料の膨潤に ともなって生ずる緩和弾性率 $\{\mathrm{Gr}(1.2)\}$ の時 間的変化 を測定した，その測定值は表 4〜6，グラフは図17〜19 に示す。これによると粉液比1.2で綀和された HSFE に おいて練和後 $\{\mathrm{Gr}(1.2)\}$ が4.0×103dyne $/ \mathrm{cm}^{2}$ なるまで の所要時間は HSFE-20；2.5分, HSFE-10；3.3分, HSFE- 5 ；5.5分，HSFE-0；14.8分であった. HSでは 


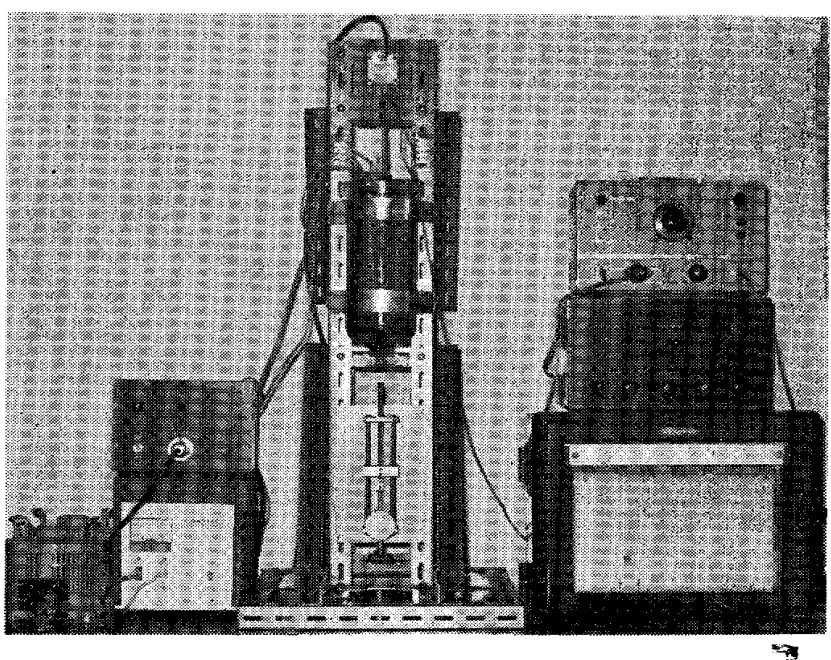

図15引張り応力緩和測定機の全景

この時間は2.5分で HSFE-20の場合と同じであった。ま た HSFE-O 以外の 4 試料は，いずれも102分付近で $\{\mathrm{Gr}$ (1.2)\} の上杽率が著しく低下する。そ低下の度合は， HSFE-20, HSFE-10, HSFE- 5 の順に少なくなり, 全 く上昇率を変えない％\%のものに接近する傾向が見られ

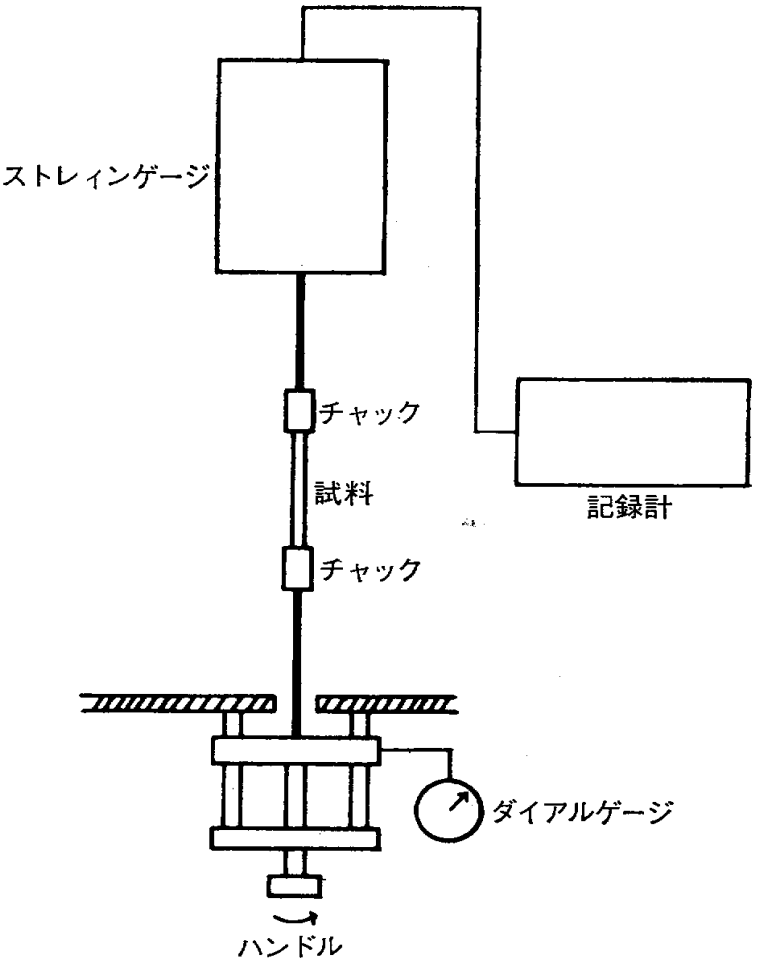

図16 引張り応力緩和測定機の構成模型図

る. 以上の傾向は粉液比 $0.8,1.2,1.4$ の場合にも認め られる. 図20〜25は図17〜19に括ける10分ならびに120 分での相対応力の時間的変化を図示したものである。測 定值は表 7 ～I2に示す。乙れによると練和開始後10分の ものでは，粉液比1.4の HSFE-10を除いた試料はいずれ

表 4 HSFEならびにHS練和物（P/L=0.8）の Gr(1.2)

単位dyne $/ \mathrm{cm}^{2}$

\begin{tabular}{|c|c|c|c|c|c|}
\hline 時間(分) 試 料 & HSFE - O & HSFE -5 & HSFE - IO & HSFE - 20 & HS \\
\hline 5 & & & $4.72 \times 10^{2}$ & $2.57 \times 10^{3}$ & $2.43 \times 10^{3}$ \\
\hline 10 & & $1.41 \times 10^{3}$ & 3. $18 \times 10^{3}$ & $3.96 \times 10^{3}$ & 3. $12 \times 10^{3}$ \\
\hline 20 & & $3.93 \times 13^{3}$ & $4.72 \times 10^{3}$ & $4.43 \times 10^{3}$ & 4. $11 \times 10^{8}$ \\
\hline 30 & & $5.08 \times 10^{3}$ & $6.94 \times 10^{3}$ & $5.26 \times 103$ & $4.75 \times 10^{3}$ \\
\hline 40 & & $9.27 \times 10^{3}$ & $7.71 \times 10^{3}$ & $5.96 \times 10^{3}$ & $5.87 \times 10^{3}$ \\
\hline 60 & $7.07 \times 10^{2}$ & 1. $39 \times 104$ & 1. $15 \times 10^{4}$ & $6.50 \times 103$ & $6.24 \times 10^{3}$ \\
\hline 80 & 1. $29 \times 108$ & $1.20 \times 104$ & 1. $43 \times 104$ & $6.81 \times 10^{3}$ & $6.76 \times 10^{3}$ \\
\hline 100 & $1.70 \times 10^{3}$ & $1.50 \times 10^{4}$ & $1.53 \times 104$ & $6.71 \times 10^{3}$ & $7.03 \times 10^{3}$ \\
\hline 120 & $2.34 \times 10^{3}$ & $1.91 \times 104$ & 1. $53 \times 104$ & & $7.25 \times 10^{8}$ \\
\hline 1190 & & & & $8.50 \times 10^{3}$ & \\
\hline 2100 & & $4.76 \times 104$ & & & \\
\hline 2730 & 1. $15 \times 105$ & & & & \\
\hline 2770 & & & $2.24 \times 104$ & & \\
\hline 4100 & & & & & 8. $41 \times 10^{3}$ \\
\hline
\end{tabular}


表 5 HSFEならびにHS練和物（P/L=1.2）のGr(l.2) 単位dyne $/ \mathrm{cm}^{2}$

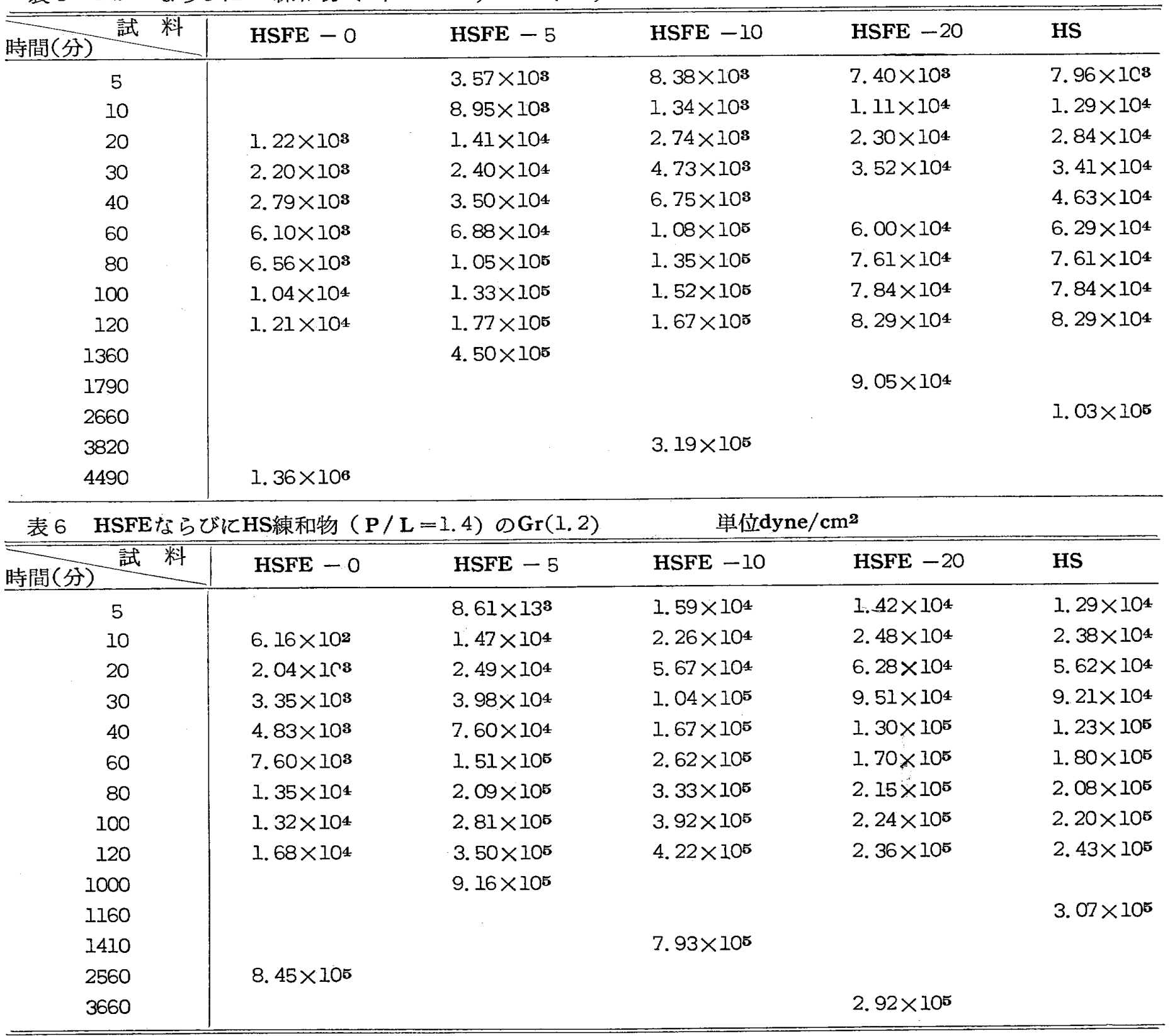

も23秒付近以後で相対応力か時間軸にほぼ平行となり著 しい応力䋸和が見られない. 練和後 120 分のものでは, HSFE-O が最も緩和しにくく，その挙動は練和開始後 10分で測定した試料の緩和挙動に類似している．相対応 力が0.9，0.8，0.5，0.2 亿まで低下するに要する時間(示 性緩和時間) は粉液比があがるにしたがって，練和後10 分，120分ともに短かくなっている．その值は表 13〜14 に示す.

図26〜28は，HSFE-20と市販品 HS，DM，HCをそれ ぞれ粉液比1.2で練和したものの練和開始後の $\{\mathrm{Gr}$ (1.2 )\}の時間的変化亡練和開始後10分およびI20分での相対 応力の時間的変化を図示したものである．乙れらの測定
値は表15〜17に示す. 図26による上，HSFE-20はHS と 同じ弾性率の上昇を示し，100分付近でともに 105 dyne/ $\mathrm{cm}^{2}$ という值となったが，HCは練和開始後4.3 分ですで に HSFE.20, HSの100 分後の 值よりも高い值を示し た.また DM は 4 試料中もっとも著しい弾性率の変化 を見せ，練和開始後100分での值は，HSFE-20，HS の それの执よそ20倍という高い值となった。罒27，28によ ると，練和開始後10分のものでは HSFE-20,HS が他 のDM，HC に比べて緩和しにくく，練和開始後120分で は逆に著しく緩和しやすくなるという結果が得られた。 これはまた相対応力が，0.9，0.8，0.5，0.2になるまで 
表 7 HSFE練和物 $(\mathrm{P} / \mathrm{L}=0.8)$ の $(\mathrm{t}) / \mathrm{s}(1.2)$ 一 練和後 10 分 -

\begin{tabular}{c|ccc}
\hline \hline 時間(秒) & HSFE - & HSFE - 10 & HSFE - 20 \\
\hline 1.2 & 1.000 & 1.000 & 1.000 \\
2 & 0.722 & 0.889 & 0.821 \\
4 & 0.556 & 0.667 & 0.643 \\
6 & 0.444 & 0.622 & 0.643 \\
10 & 0.278 & 0.556 & 0.536 \\
15 & 0.278 & 0.511 & 0.536 \\
20 & 0.278 & 0.444 & 0.536 \\
30 & 0.278 & 0.400 & 0.536 \\
60 & 0.278 & 0.400 & 0.536 \\
90 & 0.278 & 0.333 & 0.536 \\
\hline
\end{tabular}

表 8 HSFE練和物 $(\mathrm{P} / \mathrm{L}=0.8) の \mathrm{~s}(\mathrm{t}) / \mathrm{s}(1.2)$ 一 練和後 120 分 -

\begin{tabular}{|c|c|c|c|c|}
\hline 時間(秒) & HSFE - O & $\mathrm{HSFE}-5$ & HSFE - 10 & HSFE -20 \\
\hline 1.2 & 1.000 & 1.000 & 1.000 & 1.000 \\
\hline 2 & 0.848 & 0.657 & 0.656 & 0.645 \\
\hline 4 & 0.606 & 0.400 & 0.372 & 0.430 \\
\hline 6 & 0.545 & 0.314 & 0.290 & 0.355 \\
\hline 10 & 0.455 & 0.229 & 0.208 & 0.301 \\
\hline 15 & 0.394 & 0.200 & 0.180 & 0.269 \\
\hline 20 & 0.394 & 0.171 & 0.153 & 0.247 \\
\hline 30 & 0.394 & 0.171 & 0.137 & 0.215 \\
\hline 60 & 0.394 & 0.143 & 0.109 & 0. 194 \\
\hline 90 & 0.303 & 0.114 & 0.082 & 0.161 \\
\hline
\end{tabular}

表 9 HSFE練和物 $(\mathrm{P} / \mathrm{L}=1.2)$ $\mathrm{s}(\mathrm{t}) / \mathrm{s}(1.2)$ 一 練和後10分 -

\begin{tabular}{c|ccc}
\hline \hline 時間(秒) & HSFE-5 & HSFE-10 & HSFE -20 \\
\hline 1.2 & 1.000 & 1.000 & 1.000 \\
2 & 0.875 & 0.784 & 0.759 \\
4 & 0.692 & 0.622 & 0.552 \\
6 & 0.625 & 0.568 & 0.500 \\
10 & 0.567 & 0.459 & 0.397 \\
15 & 0.525 & 0.432 & 0.397 \\
20 & 0.483 & 0.405 & \\
30 & 0.442 & 0.378 & \\
60 & 0.400 & 0.324 & \\
90 & 0.400 & & \\
\hline
\end{tabular}

表10 HSFE練和物 $(\mathrm{P} / \mathrm{L}=1.2) の \mathrm{~s}(\mathrm{t}) / \mathrm{s}(1.2)$ 一 練和後 120 分 -

\begin{tabular}{|c|c|c|c|c|}
\hline 時間(秒) & HSFE $-O$ & HSFE - 5 & HSFE - 10 & HSFE -20 \\
\hline 1.2 & 1.000 & 1.000 & 1.000 & 1.000 \\
\hline 2 & 0.833 & 0.644 & 0.663 & 0.634 \\
\hline 4 & 0.658 & 0.378 & 0.350 & 0.390 \\
\hline 6 & 0.570 & 0.244 & 0.250 & 0.280 \\
\hline 10 & 0.504 & 0.156 & 0.163 & 0.195 \\
\hline 15 & 0.452 & 0.133 & 0.113 & 0.146 \\
\hline 20 & 0.408 & 0.111 & 0.088 & 0.122 \\
\hline 30 & 0.373 & 0.067 & 0.063 & 0.098 \\
\hline 60 & 0.320 & 0.044 & 0.038 & 0.073 \\
\hline 90 & 0.276 & 0.022 & 0.038 & 0.073 \\
\hline
\end{tabular}

表11 HSFE練和物 $(\mathrm{P} / \mathrm{L}=1.4)$ $\mathrm{s}(\mathrm{t}) / \mathrm{s}(1.2)$

一 練和後10分 -

\begin{tabular}{c|ccc}
\hline \hline 時間(秒) & HSFE-5 & HSFE-10 & HSFE-20 \\
\hline 1.2 & 1.000 & 1.000 & 1.000 \\
2 & 0.862 & 0.791 & 0.714 \\
4 & 0.725 & 0.594 & 0.543 \\
6 & 0.656 & 0.525 & 0.547 \\
10 & 0.573 & 0.453 & 0.343 \\
15 & 0.528 & 0.406 & 0.314 \\
20 & 0.472 & 0.369 & 0.286 \\
30 & 0.450 & 0.322 & 0.286 \\
60 & 0.381 & 0.250 & 0.256 \\
90 & 0.344 & 0.172 & 0.257 \\
\hline
\end{tabular}

表12 HSFE練和物 $(\mathrm{P} / \mathrm{L}=1.4)$ $\mathrm{s}(\mathrm{t}) / \mathrm{s}(1.2)$

一 練和後 120 分 -

\begin{tabular}{|c|c|c|c|c|}
\hline 時間(秒) & HSFE -0 & $\mathrm{HSFE}-5$ & HSFE -10 & $\mathrm{HSFE}-2 \mathrm{O}$ \\
\hline 1.2 & 1.000 & 1.000 & 1.000 & 1.000 \\
\hline 2 & 0.819 & 0.697 & 0.753 & 0.690 \\
\hline 4 & 0.672 & 0.414 & 0.460 & 0.390 \\
\hline 6 & 0.601 & 0.303 & 0.340 & 0.280 \\
\hline 10 & 0.517 & 0. 192 & 0.219 & 0.189 \\
\hline 15 & 0.462 & 0.152 & 0.153 & O. 140 \\
\hline 20 & 0.433 & 0.121 & 0.121 & 0.110 \\
\hline 30 & 0.399 & 0.091 & 0.084 & 0.090 \\
\hline 60 & 0.328 & 0.061 & 0.070 & 0.060 \\
\hline 90 & 0.307 & 0.051 & 0.037 & 0.050 \\
\hline
\end{tabular}


表13 HSFE練和物の示性緩和時間（秒）

一 練和後10分 -

\begin{tabular}{|c|c|c|c|c|c|}
\hline $\mathrm{P} / \mathrm{L}$ & $\underset{\text { 試料 }}{\mathbf{s}(\mathbf{t}) / \mathbf{s}(1.2)}$ & 0.9 & 0.8 & 0.5 & 0.2 \\
\hline \multirow{5}{*}{0.8} & H S F E -5 & 1.5 & 1.9 & 5.0 & $*$ \\
\hline & H S & 2.0 & 3.5 & 11.0 & $*$ \\
\hline & H S F E -10 & 2.0 & 3.5 & 13.5 & $*$ \\
\hline & H S F E -20 & 2.0 & 3.5 & $*$ & $*$ \\
\hline & H S F E $-O$ & $*$ & * & $*$ & $*$ \\
\hline \multirow{5}{*}{1.2} & H S F E -20 & 1. 4 & 1.7 & 6.4 & $*$ \\
\hline & H S & 1.7 & 2.4 & 8.5 & $*$ \\
\hline & H S F E -10 & 1.7 & 2.4 & 9.0 & $*$ \\
\hline & H S F E -5 & 1.7 & 2.8 & 17.5 & $*$ \\
\hline & H S F E - O & $*$ & $*$ & $*$ & $*$ \\
\hline \multirow{5}{*}{1.4} & H S F E -10 & 1.5 & 2.0 & 7.7 & 78.0 \\
\hline & H S & I. 4 & 1.6 & 4.8 & $*$ \\
\hline & H S F E -20 & 1.4 & 1.6 & 4.8 & $*$ \\
\hline & H S F E -5 & 1.7 & 2.8 & 15.7 & $*$ \\
\hline & H S F E - O & $*$ & $*$ & * & $*$ \\
\hline
\end{tabular}

* 各 $\mathrm{s}(\mathrm{t}) / \mathrm{s}(1.2)$ の值に対する示性緩和時間か 90 秒 を越えグラフからの読みとりが不可能であったも の.
の示性緩和時間を著しく短かくしている，その值は表 18, 19亿示す.

HSFE - 20 の粘弾性挙動に類似した市販印象材 HS を 粉液比を加えて練和し，練和開始後の $\{\mathrm{Gr}(1.2)\} の$ 時間的変化を測定した。 乙れを表20，図29に示す．図29 によると粉液比が高くなるにしたがって $\{\mathrm{Gr}(1.2)\}$ の 上昇速度が大きくなる傾向を示し，いずれの粉液比の試 料も100分付近で上昇速度が大きく低下している。

図30，31は HS試料の粉液比を0.8，1.2，1.4 とし， 練和開始後10分扔よび 120 分で緩和試験を行ない，相対 応力の時間的減少をみたものである，乙の図によると， 粉液比が大きい試料ほど䌅和しやすくなる傾向が見られ た．図中の HSP の相対応力一時間曲線は，練和物中の 液が練和物の粘弾性挙動にいかなる影響をおよぼすかを 明確にするためのものである，ての曲線では測定範囲90 秒間の相対応力の減衰はほとんどみられなかった．測定 值は表21，22，25に示す.

図32，33，34は HS，DM，HCの 3 試料について粉末 だけを加熱融着したプレス試料と，粉液比を 1.2 とし練 和開始後10分，120分でそれぞれ測 定した試料との相対 応力の時間的減少を図示したものである。乙れによると

表14 HSFE 練和物の示性緩和時間（秒） 一練和後 120 分一

\begin{tabular}{|c|c|c|c|c|c|c|c|}
\hline $\mathrm{P} / \mathrm{L}$ & $\begin{array}{l}\mathrm{s}(\mathrm{t}) / \mathrm{s}(1.2) \\
\text { 試 }\end{array}$ & 0.9 & 0.8 & 0.5 & 0.2 & 0.1 & 0.05 \\
\hline \multirow{5}{*}{0.8} & H S F E -10 & 1.5 & 1.7 & 3.0 & 12.0 & * & $*$ \\
\hline & H S F E -5 & 1.3 & 1.5 & 3.2 & 14.5 & * & $*$ \\
\hline & H S & 1.3 & 1.5 & 3.5 & 32.5 & * & $*$ \\
\hline & H S F E -20 & 1.3 & 1.5 & 3.5 & 50.5 & * & $*$ \\
\hline & H S F E -0 & 1.7 & 2.5 & 8.4 & * & * & $*$ \\
\hline \multirow{5}{*}{1.2} & H S F E -10 & 1.5 & 1.8 & 3.0 & 8.0 & 18.0 & * \\
\hline & H S F E -5 & 1.5 & 1.8 & 3.0 & 8.0 & 22.5 & $*$ \\
\hline & H S & 1.3 & 1.5 & 3.0 & 8.5 & 25.0 & $*$ \\
\hline & H S F E -20 & 1.5 & 1.8 & 3.0 & 10.4 & 30.0 & * \\
\hline & $\mathrm{H} \mathrm{S} \mathrm{F} \mathrm{E}-\mathrm{O}$ & 1.7 & 2.5 & 10.0 & $*$ & $*$ & * \\
\hline \multirow{5}{*}{1.4} & H S F E -10 & 1.6 & 1.8 & 3.6 & 11.5 & 25.0 & 68.0 \\
\hline & H S & 1.5 & 1.6 & 3.0 & 9.0 & 25.0 & 75.5 \\
\hline & H S F E -20 & 1.3 & 1.5 & 3.0 & 8.5 & 25.0 & 89.0 \\
\hline & H S F E -5 & 1.3 & 1.5 & 3.0 & 8.5 & 25.0 & 89.0 \\
\hline & H S F E - O & 1.7 & 2.5 & 10.0 & 8.5 & 25.0 & $*$ \\
\hline
\end{tabular}

* 各 s (t)/s (1.2)の值に対する示性緩和時間が90秒を越えグラフからの読みとりが不可能であったもの. 
機能印象材の粘弾性に関する基礎的研究

表15 4 種の機能印象材練和物 $(\mathrm{P} / \mathrm{L}=1.2) の \mathrm{Gr}(1.2) \quad$ 単位 dyne $/ \mathrm{cm}^{2}$

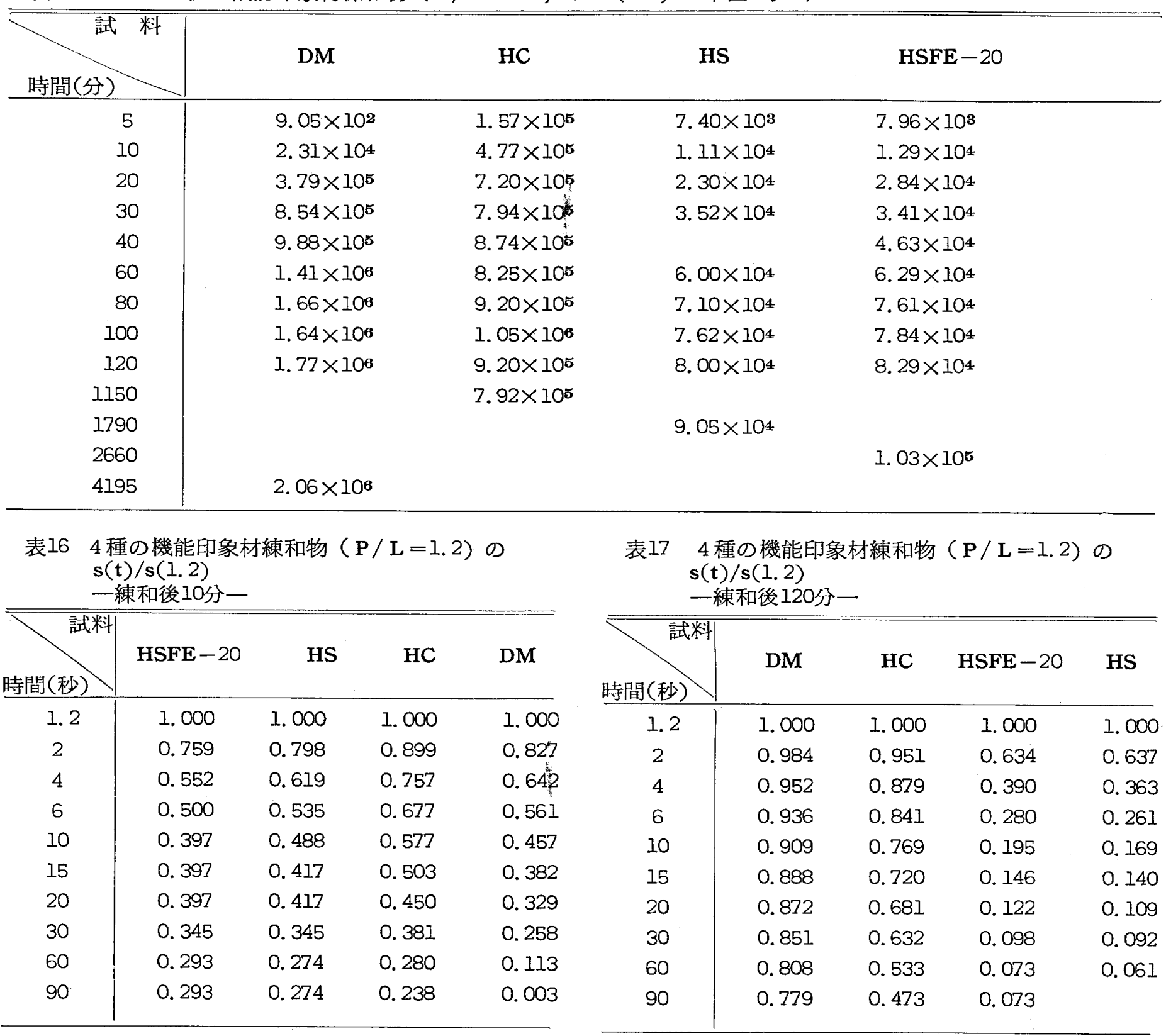

HS は練和後の経過時間が長くなると緩和しやすい練和 物となるが，DM，HCでは緩和しにくい練和物となり， DMP，HCP の挙動に近ずく傾向を示した．測定值は表 21〜25行示す.

\section{$\mathrm{V}$ 考察}

まず HSFE について考察を行なう。ずり緩和弾性率 $\{\mathrm{Gr}(\mathrm{t})\}$ は,いずれの試料においても時間とともに増 大するが，練和開始後10分付近までは，練和液中のエタ ノール含有量が多い試料ほよ゙大きな值を示し，完全膨潤 平衡に達した之思われる $2 \times 10^{3}$ 分付近では逆にエタノ ール含有量が少ない試料ほど大きな值を示す（図17〜
表18 4 種の機能印象材練和物 $(\mathrm{P} / \mathrm{L}=1.2)$ の示 性緩和時間（秒） 一練和後10分一

\begin{tabular}{|c|c|c|c|c|}
\hline $\begin{array}{l}\mathrm{s}(\mathrm{t}) / \mathrm{s}(1.2 \\
\text { 試 }\end{array}$ & 0.9 & 0.8 & 0.5 & 0.2 \\
\hline D M & 1.7 & 2.5 & 8.5 & 40.0 \\
\hline $\mathrm{H} \mathrm{C}$ & 1.8 & 2.5 & 7.0 & 72.0 \\
\hline H S & 1.8 & 2.5 & 8.5 & $*$ \\
\hline H S F E -20 & 1.4 & 1.7 & 6.4 & $*$ \\
\hline
\end{tabular}

* 各s (t)/s (1.2)の值に対する示性緩和時間が90秒 を越えグラフからの読みとりが不可能であったも の. 
表19 4 種の機能印象材練和物 $(\mathbf{P} / \mathbf{L}=1.2)$ の示性 楥和時間 (秒)

一綀和後120分一

\begin{tabular}{c|rrrr}
\hline $\mathbf{s}(\mathbf{t}) / \mathrm{s}(1.2)$ & & & & \\
& 0.9 & 0.8 & 0.5 & 0.2 \\
\hline H S & 1.4 & 1.6 & 3.0 & 9.0 \\
H S F E -20 & 1.5 & 1.8 & 3.0 & 10.4 \\
H C & 3.5 & 8.0 & 80.0 & $*$ \\
D M & 10.0 & 60.0 & $*$ & $*$ \\
\hline
\end{tabular}

* 各s(t)/s(1.2) の值に対する示性緩和時間が90秒 を越えグラフからの読みとりが不可能であったも の.

表20 HS練和物の $\mathrm{Gr}(1.2)$ 単位 dyne $/ \mathrm{cm}^{2}$

\begin{tabular}{r|ccc}
\hline \hline$P / L$ & 0.8 & 1.2 & 1.4 \\
\hline 5 & $2.43 \times 10^{3}$ & $7.96 \times 10^{3}$ & $1.29 \times 10^{4}$ \\
10 & $3.12 \times 10^{3}$ & $1.29 \times 10^{4}$ & $2.38 \times 10^{4}$ \\
20 & $4.11 \times 10^{3}$ & $2.84 \times 10^{4}$ & $5.62 \times 10^{4}$ \\
30 & $4.75 \times 10^{3}$ & $3.41 \times 10^{4}$ & $9.21 \times 10^{4}$ \\
40 & $5.87 \times 10^{3}$ & $4.63 \times 10^{4}$ & $1.23 \times 10^{5}$ \\
60 & $6.24 \times 10^{3}$ & $6.29 \times 10^{4}$ & $1.80 \times 10^{5}$ \\
80 & $6.76 \times 10^{3}$ & $7.61 \times 10^{4}$ & $2.08 \times 10^{5}$ \\
100 & $7.03 \times 10^{3}$ & $7.84 \times 10^{4}$ & $2.20 \times 10^{5}$ \\
120 & $7.25 \times 10^{3}$ & $8.29 \times 10^{4}$ & $2.43 \times 10^{5}$ \\
1166 & & & $3.07 \times 10^{5}$ \\
2660 & & & \\
4100 & $8.41 \times 10^{3}$ & & \\
\hline
\end{tabular}

表21 H S 練和物の $\mathrm{s}(\mathrm{t}) / \mathrm{s}(1.2)$ 一練和後10分一

\begin{tabular}{c|ccc}
\hline $\mathbf{P} / \mathbf{L}$ & & & \\
\hline 時間(秒) & 0.8 & 1.2 & 1.4 \\
\hline 1.2 & 1.000 & 1.000 & 1.000 \\
2 & 0.880 & 0.798 & 0.746 \\
4 & 0.700 & 0.619 & 0.534 \\
6 & 0.630 & 0.535 & 0.458 \\
10 & 0.530 & 0.488 & 0.373 \\
15 & 0.450 & 0.417 & 0.331 \\
20 & 0.400 & 0.417 & 0.305 \\
30 & 0.330 & 0.345 & 0.263 \\
60 & & 0.274 & 0.229 \\
90 & & 0.274 & 0.220 \\
\hline
\end{tabular}

表22 H S 練和物のs $(\mathrm{t}) / \mathrm{s}(1.2)$ 一練和後120分一

\begin{tabular}{c|ccc}
\hline P/L & & & \\
時間(秒) & 0.8 & 1.2 & 1.4 \\
\hline 1.2 & 1.000 & 1.000 & 1.000 \\
2 & 0.665 & 0.637 & 0.692 \\
4 & 0.455 & 0.363 & 0.400 \\
6 & 0.375 & 0.261 & 0.292 \\
10 & 0.302 & 0.169 & 0.200 \\
15 & 0.255 & 0.140 & 0.150 \\
20 & 0.236 & 0.109 & 0.125 \\
30 & 0.200 & 0.092 & 0.092 \\
60 & 0.175 & 0.061 & 0.067 \\
90 & 0.164 & & 0.042 \\
\hline
\end{tabular}

表23 D M練和物 $(\mathrm{P} / \mathrm{L}=1.2) の \mathrm{~s}(\mathrm{t}) / \mathrm{s}(\mathrm{I} .2)$

\begin{tabular}{c|cc}
\hline 時間(秒) & 10分 & 120 分 \\
\hline 1.2 & 1.000 & 1.000 \\
2 & 0.827 & 0.984 \\
4 & 0.642 & 0.952 \\
6 & 0.561 & 0.936 \\
10 & 0.457 & 0.909 \\
15 & 0.382 & 0.888 \\
20 & 0.329 & 0.872 \\
30 & 0.258 & 0.851 \\
60 & 0.113 & 0.808 \\
90 & 0.003 & 0.779 \\
\hline
\end{tabular}

表24 $\mathrm{HC}$ 練和物 $(\mathrm{P} / \mathrm{L}=1.2) の \mathrm{~s}(\mathrm{t}) / \mathrm{s}(1.2)$

\begin{tabular}{c|cc}
\hline & 10 分 & 120 分 \\
\hline 1.2 & & \\
\hline 2 & 1.000 & 1.000 \\
4 & 0.899 & 0.951 \\
6 & 0.757 & 0.879 \\
10 & 0.677 & 0.841 \\
15 & 0.577 & 0.769 \\
20 & 0.503 & 0.720 \\
30 & 0.450 & 0.681 \\
60 & 0.381 & 0.632 \\
90 & 0.280 & 0.533 \\
\hline
\end{tabular}




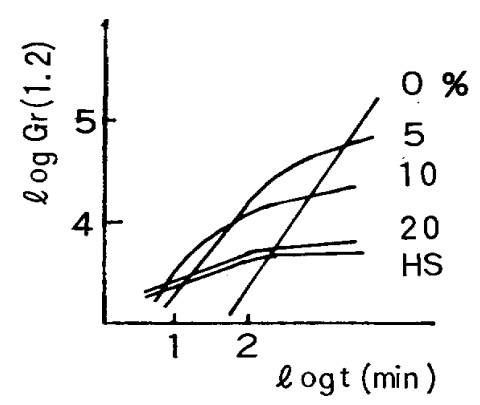

図17HSFEならびHS 練和物 $(P / L=0.8) の G r(1.2)$ 弾性率一時間曲線

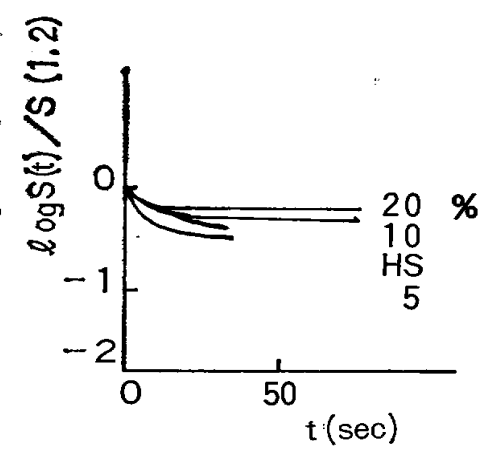

図20 HSFE練和物 $(\mathrm{P} / \mathrm{L}=0.8)$ のS (t) / S(1.2) 一練和後10分一 相対応力一時間曲線

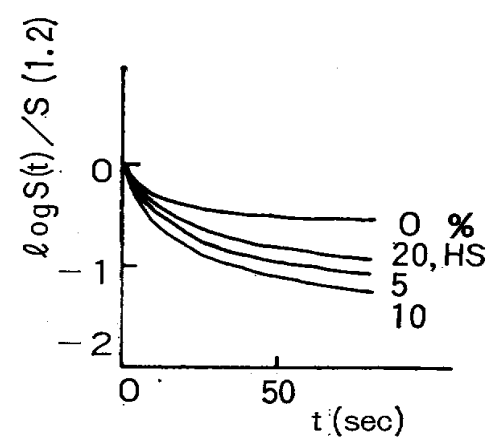

図23 HSFE練和物 $(P / L=0.8)$ の $\mathrm{S}(\mathrm{t}) / \mathrm{S}(1.2)$ - 練和後120分相対応力一時間曲線

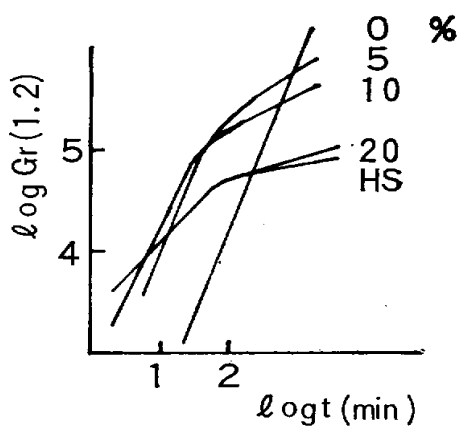

図18HSFEならびにHS練和物 $(P / L=1.2) の G r(1.2)$ 弾性率一時間曲線

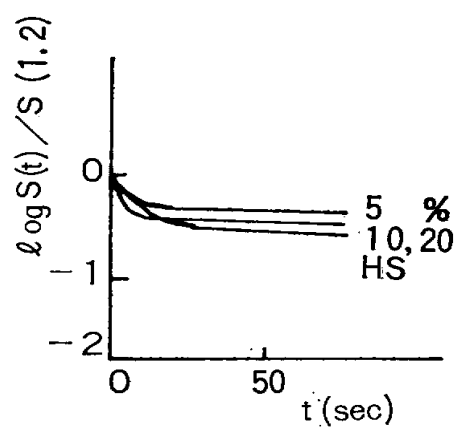

図21 HSFE綀和物 $(P / L=1.2)$ の $S(\mathrm{t}) / \mathrm{S}(1.2)$ 一練和後10分一 相対応力一時間曲線
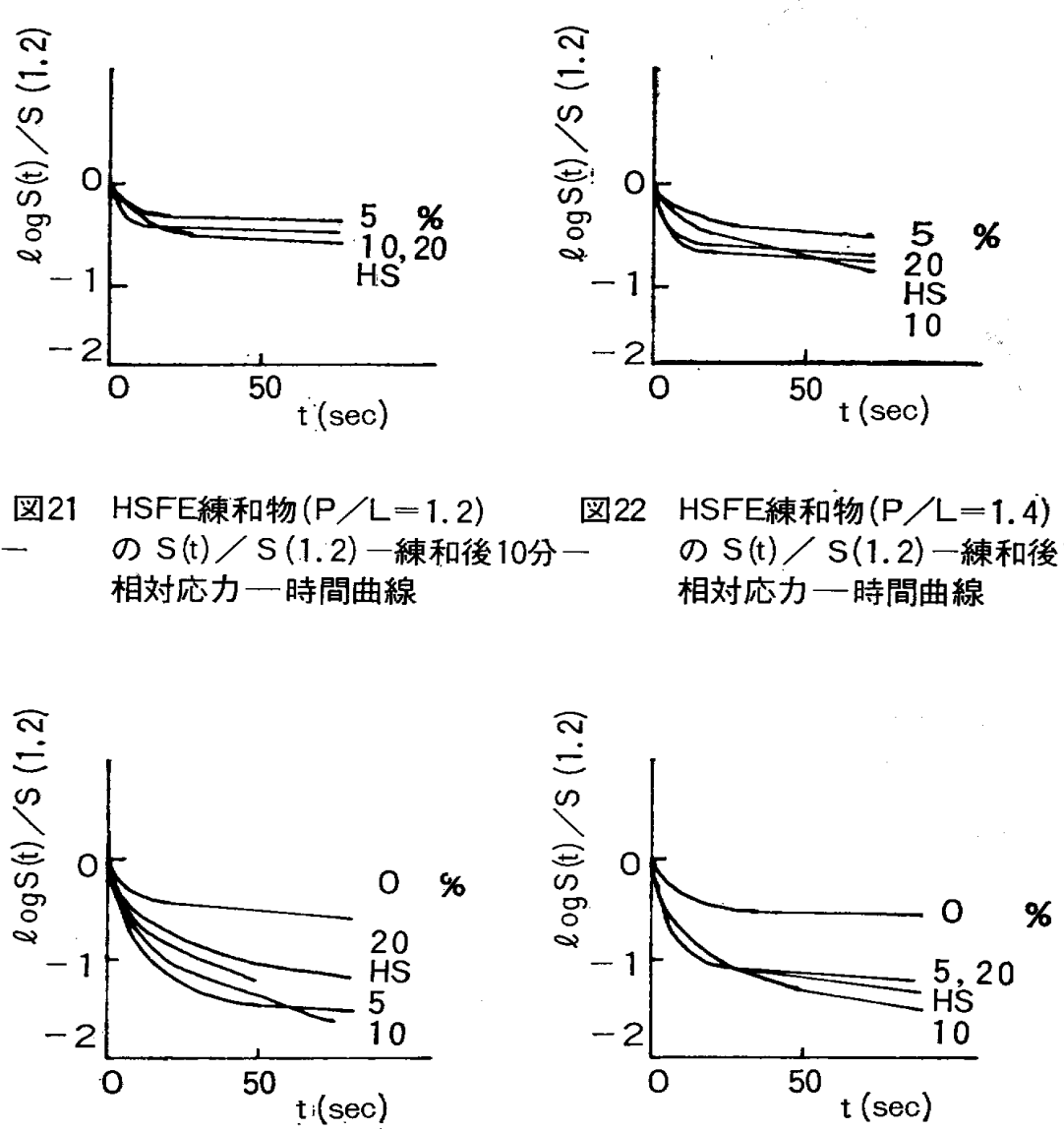

図24HSFE練和物 $(P / L=1.2)$ の $S(t) / S(1.2)$ 一練和後 120 分 相対応力一時間曲線
図22 HSFE練和物 $(P / L=1.4)$ の $\mathrm{S}(\mathrm{t}) / \mathrm{S}(1.2)$ 一練和後 10分一 相対応力一時間曲線

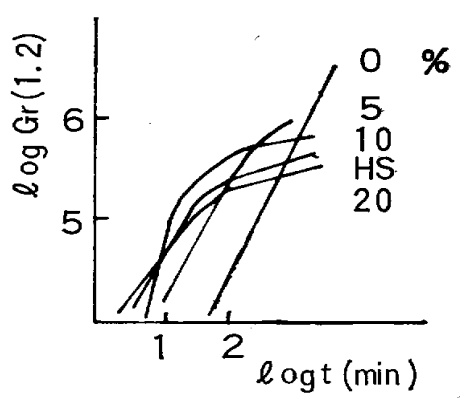

図19HSFEならびにHS練和物 $(P / L=1.4) \sigma \operatorname{Gr}(1.2)$ 弾性率一時間曲線

図25HSFE練和物 $(P / L=1.4)$ の $S(t) / S(1.2)$ 一練和後 120 分 相対応力一時間曲線 


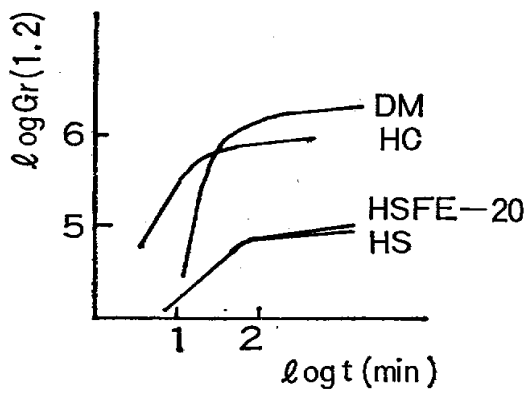

図264種の機能印象材練和物 $(P / L=1.2) の G r(1.2)$ 弾性率一時間曲線

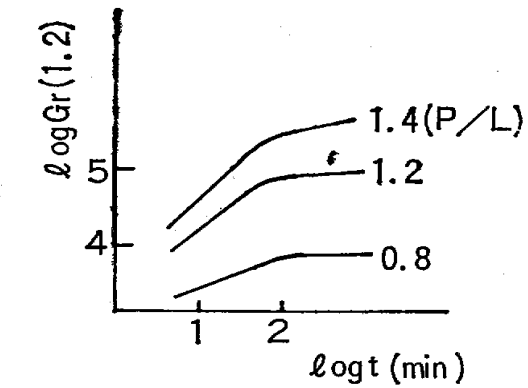

図29HS練和物の $\operatorname{Gr}(1.2)$ 弾性率一時間曲線

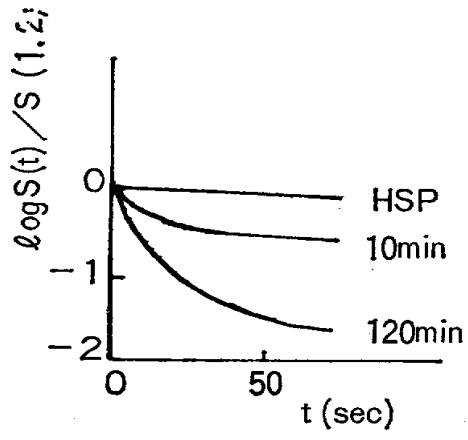

図32 $H S$ 練和物 $(P / L=1.2)$ およ びHSPの $S(t) / S(1.2)$ 相対応力一時間曲線

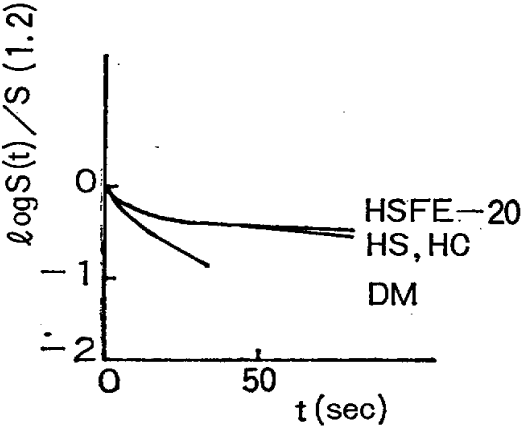

図274種の機能印象材練和物 $(\mathrm{P} / \mathrm{L}=1.2)$ $\mathrm{S}(\mathrm{t}) / \mathrm{S}(1: 2)$ 一練和後10分一

相対応力一時間曲線

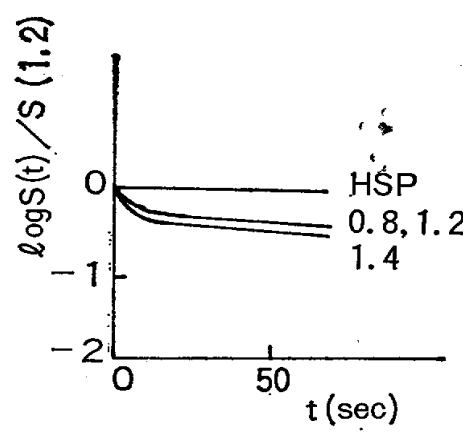

図30 HS練和物の S(t) / S (1.2) 一練和後 10 分 相対応力一時間曲線

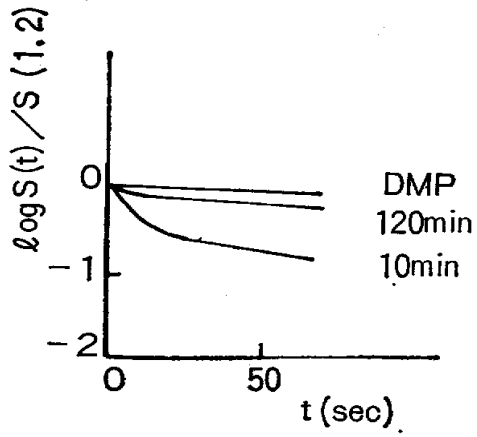

図33DM練和物 $(P / L=1.2)$ およ びDMPの $\mathrm{S}(\mathrm{t}) / \mathrm{S}(1.2)$ 相対応力一時間曲線

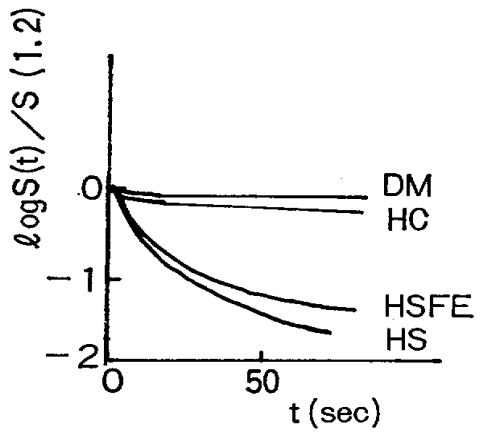

図284種の機能印象材練和物 $(\mathrm{P} / \mathrm{L}=1.2) \sigma \mathrm{S}(\mathrm{t}) / \mathrm{S}(1.2)$ 一練和後 120 分一 相対応力一時間曲線

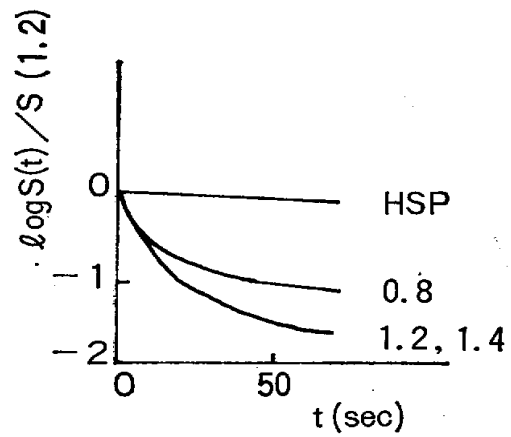

图31 HS練和物の S (t) / S (1.2) 一練和後 120分一 相対応力一時間曲線

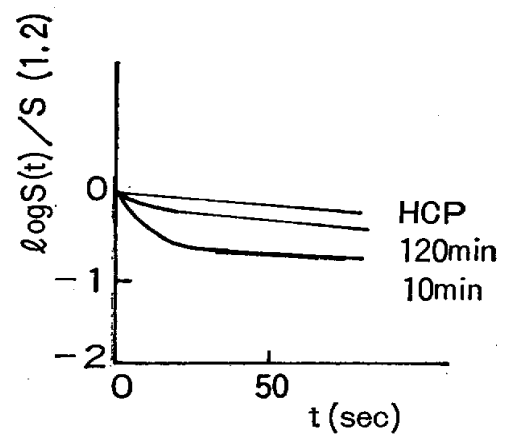

図34 HC練和物 $(P / L=1.2)$ およ びHCPの $\mathrm{S}(\mathrm{t}) / \mathrm{S}(1.2)$ 相対応力一時間曲線 
表25 3 種のプレス試料の $\mathbf{f}(\mathbf{t}) / \mathbf{f}(1.2)$

\begin{tabular}{c|lll}
\hline 試料 & H C P & D M P & H S P \\
\hline 時間(秒) & & & \\
\hline 5 & 0.941 & 0.988 & 0.990 \\
10 & 0.894 & 0.977 & 0.983 \\
15 & 0.866 & 0.971 & 0.979 \\
25 & 0.827 & 0.963 & 0.973 \\
40 & 0.787 & 0.955 & 0.965 \\
60 & 0.752 & 0.948 & 0.956 \\
100 & 0.711 & 0.938 & 0.946 \\
\hline
\end{tabular}

19）。 乙の上うに反応初期（練和開始後10分まで）にお いては, エタノール含有量の高いものほ が大きくなっているのは，エタノールがその時期におい ては反応促進剤として作用しているからであると推測さ れるが，ての作用はしだいに弱まり練和物が膨潤平衡に 達するにつれて, エタノールは単なる可塑剂として作用 するようになり, 完全平衡に達した時点ではエタノール 含有量の大きなものほどその可塑化の程度が大きくなる ものと考えられる。応の初期に印象採得開始に適した 比較的高い $\{\mathrm{Gr}(\mathrm{t})\}$ 亿急速侄到達し，しかも膨潤平衡 に達してからの $\{\mathrm{Gr}(\mathrm{t})\}$ はあまり高くないという性 質は，臨床上好ましいものと考えるので，さらにアルコ 一ル量を多くした試料を試作して同様の測 定を行なっ た。しかし練和液中のエタノール量が30\%を越えると接 着性が著しく低下し，プレート面でのすべりが生ずるた ぬ,ずり応力緩和測定は不可能になった。

相対応力の減少率の測定により，練和開始後 10分の ものが，120分のものよりも緩和しにくいという結果が 得られた。これはつぎのような理由によるもの上考えら れる。

顕微鏡観察（図 4，7，10）で明らかなように，粉末 粒子が練和液中に溶解し，均一な溶液となっていくた め，液中に残存する溶質（粉末粒子）の体積が小さくな り，その量も減少する，したがって溶液中に残存する溶 質粒子は，たがいに移動しやすくなり，練和後の放置時 間が長い試料ほど緩和しやすくなるのであろう。

つぎに HS，DM，HCの3試料について考察を行な う.HSの緩和挙動はHSFEのそれとよく類似しているか ら，てれらは同じ緩和 機構を有するものと考えられる が，DM，HCの 2 試料は上記の 2 試料とは全く異った緩 和挙動を示す.

DM，HCでは，HS，HSFEとは逆に練和後の放置時間 の長いものほど相対応力の減少率が小さく，緩和しにく
くなっている.乙の種の試料では, HS, HSFE に見ら れる溶解現象は顕微鏡観察に打いて明確に認め得なか った。粉末粒子中の可溶性の部分だけが徐々に溶解し, 練和物の粘度を上昇させているものと思わ机る（図5， $6 ， 8 ， 9 ， 11 ， 12 ）$ ．したがって，不溶分散䊀子の液 中での運動は起こりにくく，緩和しにくいものと考えら れる.

\section{VI む す ひ}

以上の考察からつぎのととが結論づけられる.

1 現在市販の機能印象材に 2 種類のタイプがある. その】つは練和液中に完全に溶解し，均一な濃厚溶液之 なるもの，いま1つは可溶性部分と不溶性部分の混和物 からなるものである．前者は練和後の時間経過にともな って緩和しやすい材料となるが，後者は緩和しにくい材 料となる傾向を有する。

$2 \mathrm{DM}, \mathrm{HC}$ タイプの試料はHSタイプの試料に比 べ,ずり緩和弾性率 $\{\operatorname{Gr}(1.2)\}$ が高い.

3 エタノールは膨潤速度を速める促進剤として作用 するとともに可塑剤としても働き，機能印象の目的には 好都合である。しかし練和液中のエタノール量が30\%を 越えると接着性が著しく低下するので，エタノール量を 極端に増やすことはできない。

4 粉液比 $(\mathrm{P} / \mathrm{L})$ を大きくするとずり緩和弾性率は 高くなる。

\section{VII 臨 床 的 考 察}

機能印象材は，咀しゃく運動，あるいは会話などの際 にロ腔内組織よりうける抑制に対し，機能上適合した印 象を採得するための印象材であるが，理想的な印象材の 機械的あるいは化学的所要性質を決定するには，口腔内 組織加らうる力, 被印象体の力学的性質, あるいは口 腔内の化学的諸条件を充分理解した上でなりればならな い28 33). したがって本実験だけで機能印象材の良否を 決定することは不可能なことである，それゅえ，本実験 の目的とした, 外力による印象材側の変形のしやすさと いう点のみから 2 〜 の検討を加えることにする.

口腔粘膜よりうける力によって材料が永久変形を起て し，口腔内の機能印象がうまく採得できるためには，印 象材は適度の弾性を持ち, しかも緩和時間が比較的短か いことが必要である34,35). この条件を満たすには，HSF E，HS タイプの印象材が適していると思われる（図32 ).とのタイプの印象材は，練和後の時間経過にともな って粘度が低下し，緩和しやすい材料に変化していくか 
らである． DM， HCタイプの材料では，練和後の時間が 経過するにしたがって粘度が高くなり，緩和しにくくな る. このてとは口腔内に長時間挿入しておいたとして も，その効果があまり現われない可能性がある。 またて のタイプの材料は先のタイプのものと比較して, 練和後 120 分での弾性率が約20倍である。したがって口腔内組 織に密着させ機能的印象を忠実に採得する点からだけ見 れば，HSFE，HSタイプのものの方が好ましいと考えら れるが，長時間側でそれほど大きな変形を必要としない ケースに対しては問題にしなくてよいであろう.

稿を終るにのぞみ, 本研究に終始愳切なるご指導とご 校閲いただいた恩師林一郎教授に深く感謝の意を表する 上ともに，実験上数多くので教示をいただいた井上勝一 郎助教授に衰心より謝意を捧げます。また本研究に種々 ご協力いただいた教室員一同に謝意を表わします。

なお，本実験に対し装置の使用を快くお許しいただ き,さらに何かとで助言を賜った九大工学部高柳素夫教 授ならびに梶山先生および同教室員の皆椂に心からなる 謝意老表わします。

\section{文献}

1. Heath, M.R. ; Functional Impression Materials (Tissue Conditioners), Some Clinical Aspects ; Dent. Pract., 17, 84 86, (1966).

2. Berry, D. C. ; A Functional Impression Materials ; Dent. Pract., 13, 289 290, (1963).

3. Chase, W. W. ; J. Pros. Dent., 11, 804, (1961).

4. Wilson, H. J., Tomlin, H. R., and Osborne, J. ; Tissue Conditioners and Functional Impression Materials ; Brit. Dent. J., 121, $9 \sim 16$, (1966).

5. Boos, D. C. ; Preperation and conditioning of patients for prosthetic treatment : J. Pros. Dent., 9, 4 10 (1959).

6. Boucher, L. J; Tissue Treatment and Function Impression Material : Mich State Dent. Ass. J., 45, 1-4, (1963).

7. Boucher, L. J ; J. Mich. Dent. Soc., 45, 377, (1963).

8. Braden, M. ; Paper presented at the British Society for the Study of Prosthetic Dentistry, (1965).

9. Lytle, R. B. ; J. Pros. Dent., 9, 539, (1959).

10. Vig, R. G; J. Pros. Dent., 14, 214, (1964).
11. Wilson, H. J. ; J. Brit. Dent. 117, 536, (1964).

12. 川上道夫, 竹花庄治; Dynamic impression material のクリープとその回復: 粜科工学雑誌, 6 (10 ), 7-11, (1965).

13. 川上道夫 ; 愛知学院大歯誌, 2(1), (1964).

14. 津留宏道; 総義歯の基本問題とダイナミック印象法 : G-C 臨床シリーズ3l, G.C 化学工業 K.K. (1970).

15. J. Jantzen; Funkt Abdrucknahme mit vorhandenem Zahnersatz : D. Z.Z, 10, 7, 654 656, (1955).

16. 後藤廉平他 2 名; レオロジーとその応用, 312 , 共 立出版 K. K. (1970).

17. 金竹哲也; 㐘科理工学通論, 267一-268, 永末書店, (1970).

18. Braden, M. ; Tisue Conditioners, I. Composition and Structure : J. Dent. Res. , 49, 145-148, (1970).

19. Braden, M. ; Tissue Conditioners II. Rheologic Properties : J.Dent. Res., 49, 496-501, (1970).

20. 高分子学会; レオロジーハンドブック, 463, 丸善, (1965).

21. 井上勝一郎, 林一郎; 歯科用レジンの動的粘弾性 : 歯科理工学雑誌，9(16), 11-12, (1968).

22. 寺沢寛一; 新訂物理学, $71-75$, 裳華房.

23. 藤山光美他 2 名；工業化学雑誌， 71，540-545, (1968).

24. 藤山光美, 高柳素夫; 工業化学雑誌 ; 2, 1163-1168

25. 須ノ内勇次郎; 九州歯科学会雑誌, $24(5), 581$ -582, (1971).

26. 後藤廉平他 2 名; レオロジーとその応用, $27-28$, 共立出版 K. K. ，(1970).

27. 井上勝一郎他 2 名; 合成ゴム印象材の応力緩和挙動 について：歯科理工学雑誌, 9 (17), 193, (1968).

28. Chase, W. W. ; Tissue Conditioning Utiliying Dynamic Adaptive Stress : J. Pros. Dent., 11, 804-815, (1961).

29. Roberts, A. L. ; Principles of Full Denture Impression Making and Thein Application in Practice : J. Pros. Dent., 1, 213-228, (1951).

30. Ryge, G., and Fairhurst, C. W. ; J. Pros. Dent., 9, 755-760, (1959).

31. Terrell, W. H. ; Relines, Rebases, or Transfers and Repairs: J. Pros. Dent. , 1, 244-253, (1951). 
32. Schulty, A. W. ; Comfort and Chewing Efficiency in Denturs : J. Pros. Dent., 1, 38-48, (1951).

33. Boucher, C. O. ; Impression Building : D. Survey, 22, 2062-2068, (1946).

34. Lytle, R B. ; The Management of Abused Oral
Tissues in Complete Denture Construction: J. Pros. Dent., 7, 27-42, (1957).

35. Lythe, R. B. ; Complete Denture Construction Based on a Study of the Deformation of the Underlying Soft Tissue : J. Pros. Dent., 9, 539-551, (1959). 